\title{
molecules
}

ISSN 1420-3049

www.mdpi.com/journal/molecules

Review

\section{The Application of Ribozymes and DNAzymes in Muscle and Brain}

Nikolaos P. Mastroyiannopoulos ${ }^{1}$, James B. Uney ${ }^{2}$ and Leonidas A. Phylactou ${ }^{1, *}$

1 Department of Molecular Genetics, Function \& Therapy, The Cyprus Institute of Neurology \& Genetics. PO Box 23462, Nicosia, Cyprus

2 Henry Welcome Laboratories for Integrative Neurosciences and Endocrinology, University of Bristol, Whilston street, Bristol, BS13NY, UK

* Author to whom correspondence should be addressed; E-Mail: laphylac@cing.ac.cy;

Tel.:+357 223582600; Fax: +357 22392817.

Received: 18 June 2010; in revised form: 3 August 2010 / Accepted: 5 August 2010 /

Published: 9 August 2010

\begin{abstract}
The discovery of catalytic nucleic acids (CNAs) has provided scientists with valuable tools for the identification of new therapies for several untreated diseases through down regulation or modulation of endogenous gene expression involved in these ailments. These CNAs aim either towards the elimination or repair of pathological gene expression. Ribozymes, a class of CNAs, can be mostly used to down-regulate (by RNA cleavage) or repair (by RNA trans-splicing) unwanted gene expression involved in disease. DNAzymes, derived by in vitro selection processes are also able to bind and cleave RNA targets and therefore down-regulate gene expression. The purpose of this review is to present and discuss several applications of ribozymes and DNAzymes in muscle and brain. There are several diseases which affect muscle and brain and catalytic nucleic acids have been used as tools to target specific cellular transcripts involved in these groups of diseases.
\end{abstract}

Keywords: catalytic nucleic acids; ribozyme; DNAzyme; brain; muscle

\section{Introduction}

Selective gene silencing by catalytic nucleic acids is a field that has been used with great success for studying natural processes in muscle and brain. Furthermore, these catalytic nucleic acids have been widely used for establishing novel gene therapy approaches for many muscle and brain diseases. 
In most cases, catalytic nucleic acids aim towards either the elimination or repair of pathological transcripts. Catalytic nucleic acids can be separated into two main categories: ribozymes and DNAzymes. Ribozymes, the most extensively studied of the catalytic nucleic acids, exist in a range of distinct categories of naturally occurring catalytic RNA. These include a series of small ribozymes important for the rolling circle replication of viroid genomes, such as hammerhead and hairpin ribozymes [1-3], group I introns [4-6], the RNA component of RNase P [7], and hepatitis delta virus ribozyme [8]. Several recent reviews have described and discussed the various catalytic nucleic acids $[6,9,10]$. The hammerhead, hairpin and hepatitis delta virus (HDV) ribozyme motifs can be characterized by their ability for self-cleavage of a particular phosphodiester bond [9,11]. Hammerhead ribozymes have the ability to suppress gene expression through specific cleavage of RNA molecules [9]. Group I Intron ribozymes can be characterized by their capacity for self-splicing by cleavage and ligation of phosphodiester bonds [6,11]. Group I intron ribozymes can be designed to act in trans by recognition and separation of RNA molecules in a sequence specific manner, and ligation of a new RNA sequence to the separated RNA molecules [6]. DNAzymes, by contrast to ribozymes, have not been observed in nature and are derived by in vitro selection processes. One of the most characterized DNAzyme is the 10-23 subtype consisting of a cation-dependent catalytic core of 15 deoxyribonucleotides that binds to and cleaves its target RNA between an unpaired purine and paired pyrimidine through a de-esterification reaction $[10,12]$. The catalytic activity and specificity of both ribozymes and DNAzymes has been extensively characterized in vitro and in cell culture systems. A wide range of chemical modifications has allowed the synthesis of oligonucleotides with in vivo stability approaching that of most conventional drugs [13].

Beside ribozymes and DNAzymes, advances in molecular genetics have revealed new tools for selective gene silencing. Small interfering RNAs (siRNAs) are single strands of RNA, approximately 20 nucleotides long, which are able to target, cleave and inactivate specific mRNAs [14]. This powerful tool for the down regulation of mRNA levels is widely used for the potential treatment of many diseases $[15,16]$. The high specificity and suppression of pathogenic RNA by using siRNA technology proves to be of high expectations. Nevertheless, like ribozymes and DNAzymes, siRNA technology shows some limitation on the selectivity, delivery and stability [14]. Efficient delivery and distribution of oligonucleotide compounds both intracellularly and in vivo remains a critical challenge for successful transition from the laboratory to the clinic.

Beside siRNAs, antisense oligonucleotides have been used to inhibit gene expression levels both in vitro and in vivo [17]. Antisense oligonucleotides usually consist of 18-25 bases long in antisense orientation to the mRNA of interest. Hybridization of the antisense oligo to the target mRNA results in RNAse $\mathrm{H}$ cleavage of the mRNA and prevents protein translation thereby blocks gene expression [18]. During the last twenty years, antisense oligonucleotides have been widely used in basic research, genomics and drug discovery. This review will focus on the use of ribozymes and DNAzymes towards the study and potential therapy of muscle and brain diseases. 


\section{The Use of Ribozymes and DNAzymes in Muscle}

Ribozymes and DNAzymes have been widely used towards the better understanding and therapy of various skeletal and smooth muscle disorders. Myotonic dystrophy type I, myotonia congenita and neuromuscular junction abnormalities, restenosis of coronary arteries and hypertension are some of the disorders that scientists introduced the use of ribozymes and DNAzymes (Figure 1).

Figure 1. Strategies for the study or therapy of muscle and brain diseases by using ribozymes and DNAzymes.
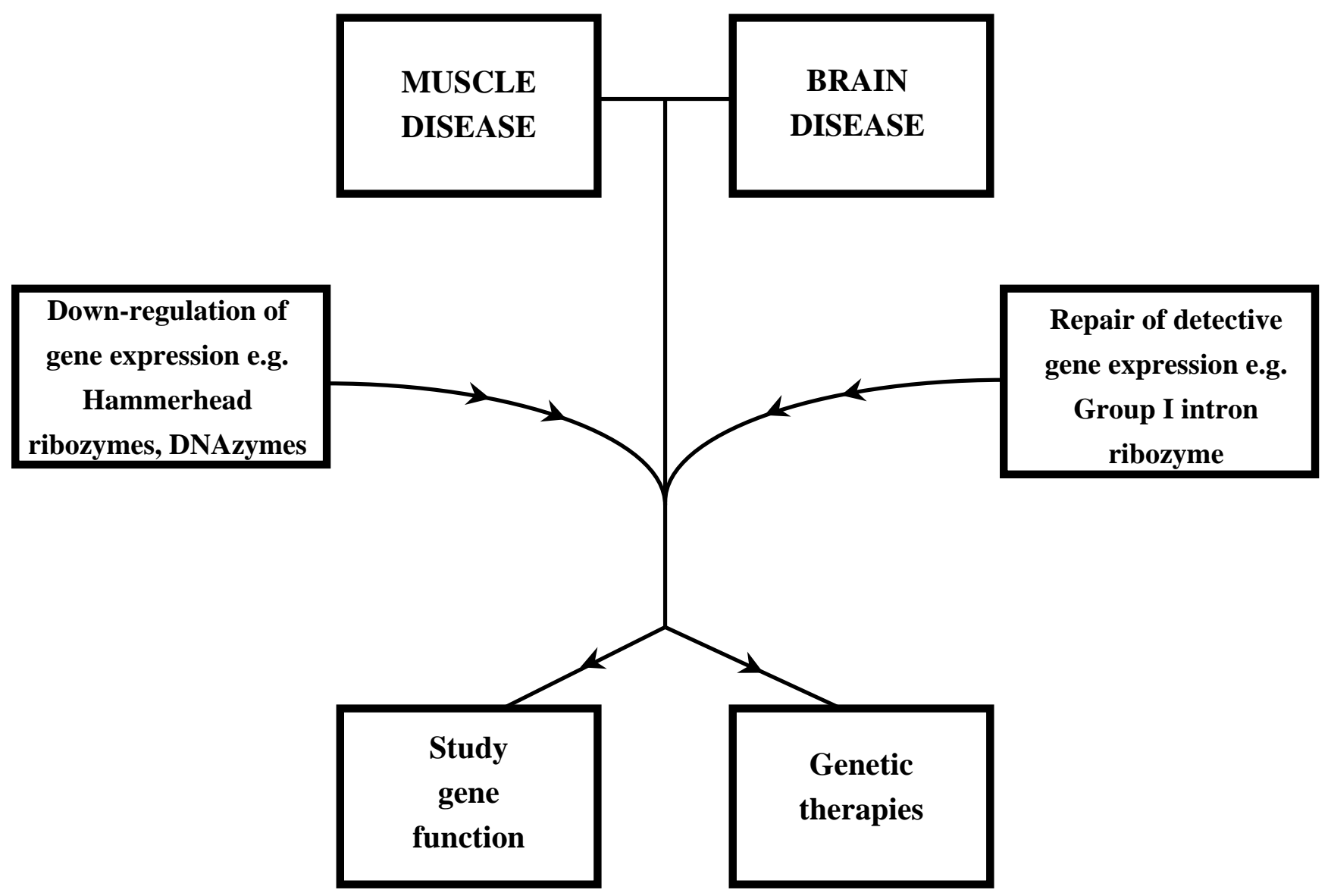

In this review, we will focus on different strategies implicating the function of ribozymes and DNAzymes in the pathomechanisms and therapy of these disorders (Table 1).

Table 1. Ribozymes and DNAzymes used for the elimination or repair of pathogenic gene expression involved in different muscle and brain diseases.

\begin{tabular}{|llll|}
\hline Ribozyme-DNAzyme & Disease & Gene-Gene target & Reference \\
\hline Hammerhead ribozyme & $\begin{array}{l}\text { Vascular smooth muscle } \\
\text { cell hypertrophy- } \\
\text { Restenosis }\end{array}$ & $\begin{array}{l}\text { Leukocyte-type 12- } \\
\text { lipoxygenase (12-LO) }\end{array}$ & $\begin{array}{l}\text { Gu, J.L., et.al. Circ. Res. 1995, 77, } \\
14-20\end{array}$ \\
\hline Hammerhead ribozyme & $\begin{array}{l}\text { Vascular smooth muscle } \\
\text { cell hypertrophy- } \\
\text { Restenosis }\end{array}$ & Proto-oncogene c-myb & $\begin{array}{l}\text { Jarvis, T.C., et al. } \text { RNA, 1996, 2, } \\
\text { 419-428. }\end{array}$ \\
\hline
\end{tabular}


Table 1. Cont.

\begin{tabular}{|c|c|c|c|}
\hline Hammerhead ribozyme & $\begin{array}{l}\text { Vascular smooth muscle } \\
\text { cell hypertrophy- } \\
\text { Restenosis }\end{array}$ & $\begin{array}{l}\text { Cyclin E and Cyclin } \\
\text { E2F1 }\end{array}$ & $\begin{array}{l}\text { Grassi, G., et al., J Gene Med, } \\
\text { 2005. 7(9): p. 1223-1234. }\end{array}$ \\
\hline Hammerhead ribozyme & $\begin{array}{l}\text { Myotonic Dystrophy } \\
\text { type } 1 \text { (DM1) }\end{array}$ & $\begin{array}{l}\text { Mutant DMPK 3' } \\
\text { UTR }\end{array}$ & $\begin{array}{l}\text { Langlois, M.A., et al., Mol Ther, } \\
\text { 2003. 7(5 Pt 1): p. } 670-680 .\end{array}$ \\
\hline Group I intron ribozyme & $\begin{array}{l}\text { Myotonic Dystrophy } \\
\text { type } 1 \text { (DM1) }\end{array}$ & $\begin{array}{l}\text { Mutant DMPK 3' } \\
\text { UTR }\end{array}$ & $\begin{array}{l}\text { Phylactou, L.A., et al., Nat Genet, } \\
\text { 1998. 18(4): p. } 378-381 .\end{array}$ \\
\hline Hammerhead ribozyme & $\begin{array}{l}\text { Slow channel congenital } \\
\text { myasthenic syndrome }\end{array}$ & $\begin{array}{l}\text { Acetylcholine receptor } \\
\text { (AchR) }\end{array}$ & $\begin{array}{l}\text { Abdelgany, A., et al., } \\
\text { J RNAi Gene Silencing, } \\
\text { 2005. 1(1): p. 26-31. }\end{array}$ \\
\hline DNAzyme & $\begin{array}{l}\text { Slow channel congenital } \\
\text { myasthenic syndrome }\end{array}$ & $\begin{array}{l}\text { Acetylcholine receptor } \\
(\text { AchR) }\end{array}$ & $\begin{array}{l}\text { Abdelgany, A., et al., } \\
\text { J RNAi Gene Silencing, } 2005 . \\
\text { (1): p. 32-37. }\end{array}$ \\
\hline DNAzyme & Huntington's & Huntingtin (HTT) & $\begin{array}{l}\text { Yen, L., et al., Ann Neurol, } 1999 . \\
46(3) \text { : p. 366-373. }\end{array}$ \\
\hline Hammerhead ribozyme & Alzheimer's & $\beta$-Secretase & $\begin{array}{l}\text { Nawrot, B., et al., } \\
\text { Eur J Biochem, } 2003 . \\
\text { 270(19): p. 3962-3970. }\end{array}$ \\
\hline Hammerhead ribozyme & Alzheimer's & $\begin{array}{l}\text { Dihydrolipoamide } \\
\text { succinyltransferase } \\
\text { (DLST) }\end{array}$ & $\begin{array}{l}\text { Kanamori, T., et al., } \\
\text { EMBO J, 2003. } \\
\text { 22(12): p. 2913-2923. }\end{array}$ \\
\hline Hammerhead ribozyme & Parkinson's & a-Synuclein & $\begin{array}{l}\text { Hayashita-Kinoh, H., et al., } \\
\text { Biochem Biophys Res Commun, } \\
\text { 2006. 341(4): p. 1088-1095. }\end{array}$ \\
\hline Hammerhead ribozyme & Glioblastomas & Pleiotrophin (PTN) & $\begin{array}{l}\text { Grzelinski, M., et al., Int J Cancer, } \\
2005.117(6) \text { : p. } 942-951 .\end{array}$ \\
\hline Hammerhead ribozyme & Glioblastomas & $\begin{array}{l}\text { Pleiotrophin (PTN) } \\
\text { and anaplastic } \\
\text { lymphoma kinase } \\
\text { (ALK) }\end{array}$ & $\begin{array}{l}\text { Grzelinski, M., et al., Neoplasia, } \\
\text { 2009. 11(2): p. 145-156. }\end{array}$ \\
\hline Hammerhead ribozyme & Encephalitis & $\begin{array}{l}\text { Japanese encephalitis } \\
\text { virus (JEV) }\end{array}$ & $\begin{array}{l}\text { Appaiahgari, M.B. and S. Vrati. } \\
\text { Mol Ther, 2007. 15(9): p. 1593- } \\
1599 .\end{array}$ \\
\hline
\end{tabular}

The vascular smooth muscle cell in mature animals is a highly specialized cell whose principal function is contraction and regulation of blood vessel tone-diameter, blood pressure, and blood flow distribution. However, abnormal environmental signals can lead to adverse phenotypic switching and acquisition of characteristics of smooth muscle cell that can contribute to the development and/or progression of vascular disease [19,20]. Several attempts have been reported which utilised catalytic nucleic acids in smooth muscle cells. References to several reports which demonstrate the application and usefulness of ribozymes and DNAzymes in smooth muscle cells are presented below.

Angiotensin II (Ang II) plays an important role in the development of hypertension and atherosclerosis by inducing vascular smooth muscle cell growth and synthesis of aldosterone $[21,22]$. Activation of Leukocyte-type 12-lipoxygenase (12-LO) has been proposed to be an important mechanism for AngII by inducing hypertrophy of vascular smooth muscle cells. This finding prompted scientists to design a chimeric RNA hammerhead ribozyme against the first GUC sequence at nucleotide 7 of porcine leukocyte 12-LO mRNA. The ribozyme was transfected into porcine aortic vascular smooth muscle cells, causing a significant decrease of endogenous porcine leukocyte-type 12LO mRNA and protein levels [23]. Downregulation of 12-LO levels, have the potential to protect vascular smooth muscle cells from hypertrophy [24]. The results from this study indicated the 
feasibility of using new ribozyme technology to study the specific effects of a gene pathway in vascular disease and the potential therapies.

Proliferation of injured smooth muscle cells contributes to the reocclusion or restenosis of coronary arteries that often occurs following angioplasty procedures. Coronary angioplasty is an effective procedure used in order to open occluded vessels. However, in spite of a number of technical improvements in the procedure, post-operative occlusion of arteries, or restenosis, still occurs. It is widely believed that by preventing the injury-induced activation and proliferation of medial smooth muscle cells after angioplasty, intiminal thickening and restenosis could be prevented [25]. In an attempt to inhibit smooth muscle cell proliferation, Jarvis et al. described the activity of several ribozymes targeting c-myb mRNA. Hammerhead ribozymes were capable of cleaving c-myb RNA and as a result inhibit smooth muscle cell proliferation [26]. This finding indicated that hammerhead ribozymes have the potential to inhibit the hyperproliferation of smooth muscle cells that occurs in many patients after coronary angioplasty. In another attempt to prevent restenosis in coronary arteries, Grassi et al. explored the use of hammerhead ribozymes as tools to knock down specific activators of cell proliferation. They designed two specific hammerhead ribozymes to inhibit the mRNA levels of cyclin E and E2F1, two potent activators of cell proliferation which cooperate to promote the G1 to S phase transition [27,28]. After transfecting these hammerhead ribozymes within coronary smooth muscle cells, mRNA and protein levels of cyclin E and E2F1 were significantly reduced. Furthermore, the coronary smooth muscle cell growth was dramatically shut down and almost completely prevented when the two hammerhead ribozymes were administered together [29].

Ribozymes and DNAzymes have been also used as tools to target defects in neuromuscular diseases. Myotonic Dystrophy type 1 (DM1) is a degenerative neuromuscular disease characterised by a large CTG repeat expansion situated in the 3' UTR of the DMPK gene. The mutant DMPK 3' UTR RNA containing the CUG expansion accumulate to form RNA foci in the nucleus of DM1 cells [30,31]. These RNA foci interact with nuclear RNA binding proteins preventing their export from the nucleus [32,33]. The fact that most of the disease pathomechanisms involve mutant RNA foci and their interactions to various binding proteins, prompted researchers to create specific ribozymes for the destruction of the mutant RNA. Langlois et al. identified most of the accessible ribozyme target sites in the 3' UTR of the DMPK mRNA and designed a hammerhead ribozyme to cut the most accessible site. The use of these hammerhead ribozyme significantly reduced the number of mutant DMPK mRNA-containing nuclear foci in human DM1 myoblasts. The reduction of mutant DMPK mRNA and nuclear foci had as an effect the partial restoration of insulin receptor isoform B expression in DM1 myoblasts [34].

Another approach was the use of specific ribozymes for the repair of the expanded repeat. Phylactou et al. designed a group I intron ribozyme in order to modify the CUG repeat expansion at the 3' UTR of the human DMPK transcripts. This group I intron ribozyme showed to be capable of ligating a small mRNA fragment, contained within the ribozyme, to a simple DMPK-target RNA in vitro. It also modified a larger target transcript, leading to replacement of twelve repeats with five repeats, both in vitro and in mammalian cells [35].

The mutant canine skeletal muscle chloride channel (cClC-1) mRNA transcript that causes the inherited disorder myotonia congenita, prompted scientists to further investigate the feasibility of RNA repair using specific ribozymes. Rogers et al. designed a modified Tetrahymena ribozyme to mediate 
trans-splicing repair of the mutant canine skeletal muscle chloride channel (cClC-1) mRNA transcripts. The ribozyme was able to target the mutant mRNA and replace the mutant containing 3' portion by trans-splicing the corresponding wild type sequence. Furthermore, when the chloride channel function was examined in single cells, a wide range of electrophysiological activity was observed, with $18 \%$ of cells exhibiting significant functional restoration and some cells exhibiting complete rescue of the biophysical phenotype [36].

The muscle acetylcholine receptor (AChR) is expressed at the neuromuscular junction, and plays the principal role in nerve to muscle signal transmission. A number of mutations have been characterised in the AChR -subunit gene which affect receptor function and give rise to slow channel congenital myasthenic syndrome [37,38]. Abdelgany et al. designed hammerhead ribozymes in order to target RNA transcripts from four different slow channel congenital myasthenic syndrome mutations. These hammerhead ribozymes were able to efficiently discriminate between mutant and wild type RNA transcripts that differ only by a single nucleotide substitution [39]. Furthermore, the ability of DNAzymes to cause allele-specific cleavage in transcripts where the mutation creates a putative cleavage site or full DNAzyme:target binding was tested. Alelle-specific cleavage was demonstrated in both cases under simulated physiological conditions [40].

\section{The Use of Ribozymes and DNAzymes in Brain}

The use of ribozyme and DNAzyme strategies were also introduced in various brain disorders (Figure 1). Huntington's, Alzheimer's and Parkinson's are some of brain diseases that ribozymes and DNAzymes were used for their study and therapy (Table 1). Huntington's disease (HD) is a progressive brain disorder that causes uncontrolled movements, emotional problems, and loss of thinking ability. The underlying cause of Huntington's disease is the inheritance of a copy of the gene encoding huntingtin with an expanded polyglutamine-encoding CAG repeat located within the $5^{\prime}$ end of the coding region [41]. The mutant huntingtin protein is expressed during development through adulthood, causes neuronal dysfunction, and ultimately cell death of neurons in the striatum. The neuropathology is present to a varying extent in other regions of the brain [41]. Yen et al. demonstrated the first effective destruction of the mutant huntingtin mRNA using a specific DNAzyme that was able to cleave the mutant huntingtin mRNA in a sequence-specific manner, that lead to significant reduction of mutant huntingtin protein expression in mammalian cells [42]. Therefore, with the reduction of the mutant huntingtin, several pathways associated with huntingtin were altered and less cellular toxicity was observed. Cellular and animal models showing significantly reduced huntingtin levels, reduce the severity of the disease, suggesting that HD might be reversible [43,44].

Catalytic nucleic acids have been also used in Alzheimer's disease (AD). AD is a neurodegenerative disorder involving the deposition of senile plaques in the brain. The plaques consist of aggregates of a $4 \mathrm{kDa} A \beta$-amyloid peptide $(\mathrm{A} \beta)$. The peptide is produced by sequential cleavage of the amyloid precursor protein (APP) by $\beta$ - and $\gamma$-secretases $[45,46]$. The level of $\beta$-amyloid peptide, one of the major components of toxic amyloid plaques, depends directly on the hydrolytic activity of $\beta$-secretase. Nawrot et al. designed RNA-cleaving ribozymes in order to control the expression of $\beta$-secretase. The scientific findings demonstrated that these ribozymes were able to significantly inhibit $\beta$-secretase gene expression at both the mRNA and protein levels [46]. Furthermore, the inhibition of $\beta$-site APP 
cleaving enzyme influenced the total population of $\beta$-amyloid peptide and as a result, it can be considered as a molecular tool for the anti-amyloid treatment of AD disease.

In another study, Kanamori et al. showed that an mRNA transcribed in dihydrolipoamide succinyltransferase (DLST) gene was significantly lower in the brain of AD patients compared to the controls [47]. The truncated gene product (designated MIRTD) localized to the intermembrane space of mitochondria. A dimeric hammerhead ribozyme (maxizyme) was targeted against the MIRTD transcript. SH-SY5Y neuroblastoma cells transfected with maxizyme constructs reduced MIRTD expression. The ribozyme-expressing cells had a greater sensitivity to hydrogen peroxide and a significantly reduced rate of respiration, implicating MIRTD in the assembly of the cytochrome C oxidase complex, whose defect has been a candidate of the causes of $\mathrm{AD}[47,48]$.

Data from another AD study implicated the double-stranded RNA dependent protein kinase (PKR) in disease progression [49]. A library of hammerhead ribozyme genes was employed to identify genes involved in tunicamycin-induced apoptosis of SK-N-SH cells. Results from screening the ribozyme library led to the identification of PKR, which subsequently was found to be elevated in the brains of AD patients.

Parkinson's disease (PD) is another neurodegenerative disorder which is characterized by selective degeneration of substantia nigra dopamigenic neurons and the presence of abnormal cytoplasmic aggregates of a-synuclein [50]. Scientific reports showed that a-synuclein overexpression creates toxic effects to dopaminergic neurons [51,52]. By contrast, down-regulation of a-synuclein is effective for inhibition of progressive pathogenesis of PD. Hayashita-Kinoh et al. used adeno-associated virus (AAV) vector delivery of a-synuclein ribozyme in order to test its silencing effect on degenerating nigrostriatal neurons in a PD animal model, expressing the 1-methyl-4-phenylpyridinium (MPP+) [53]. $\mathrm{MPP}+$ is a neurotoxic compound found in dopaminergic neurons and is responsible for up-regulation of a-synuclein [54]. Hayashita-Kinoh et al. designed a ribozyme against human a-synuclein gene expression and constructed a ribozyme-expressing rAAV vector (designated rAAV-SynRz). Cotransfection of rAAV-SynRz and rAAV-a-synuclein into HEK293 cells resulted in down-regulation of a-synuclein protein expression in vitro. rAAV-SynRz was then injected into the substantia nigra of $\mathrm{MPP}+$-treated rats. Cell counts of tyrosine hydroxylase (TH)-positive neurons in the substantia nigra revealed that rAAV-SynRz significantly protected $\mathrm{TH}$-positive cells against apoptotic death, compared with untransfected mice or those which were injected with a control reporter vector [53]. These results showed that the use of rAAV-SynRz allowed the survival of higher number of TH-positive neurons in substantia nigra in the MPP+ model. Furthermore, these results suggest that down-regulation of asynuclein expression could be a potentially suitable route for gene therapy of PD.

Glioblastomas are the most frequent malignant brain tumors, which can progress from lower grade gliomas or arise de novo. Glioblastomas are lethal and nearly all patients die within one year, despite treatment [55]. Ribozymes and DNAzymes have been exploited to tackle glioblastoma through RNAtargeted strategies $[55,56]$.

The secreted growth factor pleiotrophin (PTN), also called heparin binding growth-associated molecule (HB-GAM), heparin affin regulatory peptide (HARP), heparin-binding growth factor 8, heparin-binding neurotrophic factor (HBNF), or osteoblast-specific protein-1 (OSF-1) is a 15.3-kDa developmentally regulated cytokine, which shows very limited expression in normal adult tissues, but is markedly upregulated in various primary human tumors and tumor cell lines [55,57]. Scientists have 
tested the hypothesis that the growth of human glioblastomas can be controlled by regulating PTN expression. Grzelinski et al. showed in two cell lines, U87 and T98G, that stable ribozyme-targeting leads to a robust reduction of PTN mRNA and protein levels. Further investigations showed that the reduction of PTN mRNA and protein levels results in decreased migration and colony formation in both glioblastoma cell lines [55]. When the same strategy was followed in a mouse model, angiogenesis and tumor growth were markedly reduced upon PTN depletion, paralleled by decreased PTN serum levels [55]. In addition, PTN was found to signal through anaplastic lymphoma kinase (ALK) [58]. ALK was found to be upregulated in glioplastoma compared to normal brain and when bound to PTN growth stimulatory and antiapoptotic effects are mediated [59]. Grzelinski et al. used a subcutaneous tumor xenograft model in order to transfect specific ribozymes against both PTN and ALK, this had as a result the abolishment of tumor growth [60].

Clinical and experimental evidence showed that the metastasis of malignant cells from a localized tumor is directly related to the number of microvessels in the primary tumor. Tumor angiogenesis is thought to be mediated by tumour-cell-derived growth factors. PTN can induce the release of active proteolytic enzymes from endothelial cells and induce tube formation of endothelial cells in vitro. It may well be able to serve as a tumor angiogenesis factor [61]. To test the above hypothesis, Czubayko et al. transfected human melanoma cells expressing high PTN levels, found to be able to metastasize from subcutaneous tumors to the lungs of experimental animals, with ribozymes in order to reduce PTN expression levels. The reduction of PTN mRNA levels showed not to affect the growth of the melanoma cells in vitro. In nude mice, however, tumor growth and angiogenesis were decreased. Moreover, apoptosis in the tumors was increased and the metastatic spread of tumors from the subcutaneous site to the lungs was prevented [62].

Finally, DNAzymes were used against the Japanese encephalitis virus (JEV). JEV is an arthropodborne flavivirus with a single-stranded RNA genome containing non-coding regions at its 5' and 3'ends [63]. Non-coding regions have flavivirus-conserved sequences that are important for virus replication. As previously described, DNAzymes are single-stranded oligodeoxynucleotides (ODNs) with $\mathrm{Mg}^{2+}$-dependent enzymatic activity capable of cleaving single-stranded RNA at specific sites under simulated physiological conditions [64]. These DNAzymes were able to specifically target the NCRs and inhibit JEV replication in culture cells and infected animals [65]. Appaiahgari et al. showed that intra-cerebral administration of a poly-(G)(10)-tethered, phosphorothioated DNAzyme in JEVinfected mice led to more than $99.99 \%$ inhibition of virus replication in brain, resulting in a dosedependent extended lifespan or complete recovery of the infected animals [65].

\section{Conclusions}

To date, several different therapeutic attempts have been described as potential treatment approaches for many muscle and brain diseases. The use of catalytic nucleic acids and more specifically of ribozymes and DNAzymes against these diseases has shown some promise. Several approaches have already been described in the literature which reveal the potential of ribozymes and DNAzymes as tools for the study or therapy in muscle and brain diseases. The sequence-specific action which both of these categories of catalytic nucleic acids have against target RNA makes them flexible agents for the elimination or repair of pathological gene expression in muscle and brain cells. 
Particularly the trans-splicing ribozyme has the unique feature to repair mutant transcripts which are implicated in both groups of diseases. Naturally, more effort should be dedicated, particularly in the area of delivery of nucleic acids so that the effect of both ribozymes and DNAzymes is more efficient and specific.

\section{Acknowledgements}

Part of the work of the LAP laboratory was covered by financial support by the A.G. Leventis Foundation.

\section{References}

1. Rossi, J.J. Ribozymes. Curr. Opin. Biotechnol. 1992, 3, 3-7.

2. Haseloff, J.; Gerlach, W.L. Simple RNA enzymes with new and highly specific endoribonuclease activities. Nature 1988, 334, 585-591.

3. Tedeschi, C.; Briguori, C.; De Rosa, R.; Ratti, G.; Cademartiri, F.; Sacco, M.; Borrelli, F.; Tammaro, P.; Midiri, M.; Capogrosso, P. Right coronary artery arising from pulmonary trunk: Assessment with conventional coronary angiography and multislice computed tomography coronary angiography. J. Cardiovasc. Med. 2009, 10, 178-182.

4. Cech, T.R.; Zaug, A.J.; Grabowski, P.J. In vitro splicing of the ribosomal RNA precursor of Tetrahymena: Involvement of a guanosine nucleotide in the excision of the intervening sequence. Cell 1981, 27, 487-496.

5. Cech, T.R. Self-splicing of group I introns. Annu. Rev. Biochem. 1990, 59, 543-568.

6. Fiskaa, T.; Birgisdottir, A.B. RNA reprogramming and repair based on trans-splicing group I ribozymes. N. Biotechnol. 2010, 27, 194-203.

7. Guerrier-Takada, C.; Gardiner, K.; Marsh, T.; Pace, N.; Altman, S. The RNA moiety of ribonuclease $\mathrm{P}$ is the catalytic subunit of the enzyme. Cell 1983, 35, 849-857.

8. Branch, A.D.; Robertson, H.D. Efficient trans cleavage and a common structural motif for the ribozymes of the human hepatitis delta agent. Proc. Natl. Acad. Sci. USA 1991, 88, 10163-10167.

9. Tedeschi, L.; Lande, C.; Cecchettini, A.; Citti, L. Hammerhead ribozymes in therapeutic target discovery and validation. Drug Discov. Today 2009, 14, 776-783.

10. Tan, M.L.; Choong, P.F.; Dass, C.R. DNAzyme delivery systems: Getting past first base. Expert Opin. Drug Deliv. 2009, 6, 127-138.

11. Phylactou, L.A.; Kilpatrick, M.W.; Wood, M.J. Ribozymes as therapeutic tools for genetic disease. Hum. Mol. Genet. 1998, 7, 1649-1653.

12. Joyce, G.F. RNA cleavage by the 10-23 DNA enzyme. Methods Enzymol. 2001, 341, 503-517.

13. Sun, L.Q.; Cairns, M.J.; Saravolac, E.G.; Baker, A.; Gerlach, W.L. Catalytic nucleic acids: From lab to applications. Pharmacol. Rev. 2000, 52, 325-347.

14. Scanlon, K.J. Anti-genes: siRNA, ribozymes and antisense. Curr. Pharm. Biotechnol. 2004, 5, 415-420.

15. de Fougerolles, A.; Vornlocher, H.P.; Maraganore, J.; Lieberman, J. Interfering with disease: A progress report on siRNA-based therapeutics. Nat. Rev. Drug Discov. 2007, 6, 443-453. 
16. Cheng, J.C.; Moore, T.B.; Sakamoto, K.M. RNA interference and human disease. Mol. Genet. Metab. 2003, 80, 121-128.

17. Dias, N.; Stein, C.A. Antisense oligonucleotides: Basic concepts and mechanisms. Mol. Cancer Ther. 2002, 1, 347-355.

18. Bennett, C.F.; Swayze, E.E. RNA targeting therapeutics: Molecular mechanisms of antisense oligonucleotides as a therapeutic platform. Annu. Rev. Pharmacol. Toxicol. 2010, 50, 259-293.

19. Owens, G.K.; Kumar, M.S.; Wamhoff, B.R. Molecular regulation of vascular smooth muscle cell differentiation in development and disease. Physiol. Rev. 2004, 84, 767-801.

20. van Oostrom, O.; Fledderus, J.O.; de Kleijn, D.; Pasterkamp, G.; Verhaar, M.C. Smooth muscle progenitor cells: Friend or foe in vascular disease? Curr. Stem. Cell Res. Ther. 2009, 4, 131-140.

21. Mifune, M.; Sasamura, H.; Shimizu-Hirota, R.; Miyazaki, H.; Saruta, T. Angiotensin II type 2 receptors stimulate collagen synthesis in cultured vascular smooth muscle cells. Hypertension 2000, 36, 845-850.

22. Nadler, J.L.; Natarajan, R.; Stern, N. Specific action of the lipoxygenase pathway in mediating angiotensin II-induced aldosterone synthesis in isolated adrenal glomerulosa cells. J. Clin. Invest. 1987, 80, 1763-1769.

23. Gu, J.L.; Veerapanane, D.; Rossi, J.; Natarajan, R.; Thomas, L.; Nadler, J. Ribozyme-mediated inhibition of expression of leukocyte-type 12-lipoxygenase in porcine aortic vascular smooth muscle cells. Circ. Res. 1995, 77, 14-20.

24. Sasson, S.; Eckel, J. Disparate effects of 12-lipoxygenase and 12-hydroxyeicosatetraenoic acid in vascular endothelial and smooth muscle cells and in cardiomyocytes. Arch. Physiol. Biochem. 2006, 112, 119-129.

25. Forrester, J.S.; Fishbein, M.; Helfant, R.; Fagin, J. A paradigm for restenosis based on cell biology: Clues for the development of new preventive therapies. J. Am. Coll. Cardiol. 1991, 17, 758-769.

26. Jarvis, T.C.; Alby, L.J.; Beaudry, A.A.; Wincott, F.E.; Beigelman, L.; McSwiggen, J.A.; Usman, N.; Stinchcomb, D.T. Inhibition of vascular smooth muscle cell proliferation by ribozymes that cleave c-myb mRNA. RNA 1996, 2, 419-428.

27. Dyson, N. The regulation of E2F by pRB-family proteins. Genes Dev. 1998, 12, 2245-2262.

28. Ohtsubo, M.; Theodoras, A.M.; Schumacher, J.; Roberts, J.M.; Pagano, M. Human cyclin E, a nuclear protein essential for the G1-to-S phase transition. Mol. Cell Biol. 1995, 15, 2612-2624.

29. Grassi, G.; Schneider, A.; Engel, S.; Racchi, G.; Kandolf, R.; Kuhn, A. Hammerhead ribozymes targeted against cyclin E and E2F1 cooperate to down-regulate coronary smooth muscle cell proliferation. J. Gene Med. 2005, 7, 1223-1234.

30. Mahadevan, M.; Tsilfidis, C.; Sabourin, L.; Shutler, G.; Amemiya, C.; Jansen, G.; Neville, C.; Narang, M.; Barcelo, J.; O'Hoy, K.; et al. Myotonic dystrophy mutation: An unstable CTG repeat in the 3' untranslated region of the gene. Science 1992, 255, 1253-1255.

31. Brook, J.D.; McCurrach, M.E.; Harley, H.G.; Buckler, A.J.; Church, D.; Aburatani, H.; Hunter, K.; Stanton, V.P.; Thirion, J.P.; Hudson, T.; et al. Molecular basis of myotonic dystrophy: Expansion of a trinucleotide (CTG) repeat at the $3^{\prime}$ end of a transcript encoding a protein kinase family member. Cell 1992, 68, 799-808. 
32. Mankodi, A.; Urbinati, C.R.; Yuan, Q.P.; Moxley, R.T.; Sansone, V.; Krym, M.; Henderson, D.; Schalling, M.; Swanson, M.S.; Thornton, C.A. Muscleblind localizes to nuclear foci of aberrant RNA in myotonic dystrophy types 1 and 2. Hum. Mol. Genet. 2001, 10, 2165-2170.

33. Timchenko, N.A.; Cai, Z.J.; Welm, A.L.; Reddy, S.; Ashizawa, T.; Timchenko, L.T. RNA CUG repeats sequester CUGBP1 and alter protein levels and activity of CUGBP1. J. Biol. Chem. 2001, 276, 7820-7826.

34. Langlois, M.A.; Lee, N.S.; Rossi, J.J.; Puymirat, J. Hammerhead ribozyme-mediated destruction of nuclear foci in myotonic dystrophy myoblasts. Mol. Ther. 2003, 7, 670-680.

35. Phylactou, L.A.; Darrah, C.; Wood, M.J. Ribozyme-mediated trans-splicing of a trinucleotide repeat. Nat. Genet. 1998, 18, 378-381.

36. Rogers, C.S.; Vanoye, C.G.; Sullenger, B.A.; George, A.L., Jr. Functional repair of a mutant chloride channel using a trans-splicing ribozyme. J. Clin. Invest. 2002, 110, 1783-1789.

37. Croxen, R.; Newland, C.; Beeson, D.; Oosterhuis, H.; Chauplannaz, G.; Vincent, A.; NewsomDavis, J. Mutations in different functional domains of the human muscle acetylcholine receptor alpha subunit in patients with the slow-channel congenital myasthenic syndrome. Hum. Mol. Genet. 1997, 6, 767-774.

38. Marques, M.J.; Mendes, Z.T.; Minatel, E.; Santo Neto, H. Acetylcholine receptors and nerve terminal distribution at the neuromuscular junction of long-term regenerated muscle fibers. $J$. Neurocytol. 2005, 34, 387-396.

39. Abdelgany, A.; Ealing, J.; Wood, M.; Beeson, D. Selective cleavage of AChR cRNAs harbouring mutations underlying the slow channel myasthenic syndrome by hammerhead ribozymes. J. RNAi Gene Silencing 2005, 1, 26-31.

40. Abdelgany, A.; Ealing, J.; Wood, M.; Beeson, D. Selective DNAzyme-mediated cleavage of AChR mutant transcripts by targeting the mutation site or through mismatches in the binding arm. J. RNAi Gene Silencing 2005, 1, 32-37.

41. Kremer, B.; Goldberg, P.; Andrew, S.E.; Theilmann, J.; Telenius, H.; Zeisler, J.; Squitieri, F.; Lin, B.; Bassett, A.; Almqvist, E.; et al. A worldwide study of the Huntington's disease mutation. The sensitivity and specificity of measuring CAG repeats. N. Engl. J. Med. 1994, 330, 1401-1406.

42. Yen, L.; Strittmatter, S.M.; Kalb, R.G. Sequence-specific cleavage of Huntingtin mRNA by catalytic DNA. Ann. Neurol. 1999, 46, 366-373.

43. Wang, Y.L.; Liu, W.; Wada, E.; Murata, M.; Wada, K.; Kanazawa, I. Clinico-pathological rescue of a model mouse of Huntington's disease by siRNA. Neurosci. Res. 2005, 53, 241-249.

44. DiFiglia, M.; Sena-Esteves, M.; Chase, K.; Sapp, E.; Pfister, E.; Sass, M.; Yoder, J.; Reeves, P.; Pandey, R.K.; Rajeev, K.G.; Manoharan, M.; Sah, D.W.; Zamore, P.D.; Aronin, N. Therapeutic silencing of mutant huntingtin with siRNA attenuates striatal and cortical neuropathology and behavioral deficits. Proc. Natl. Acad. Sci. USA 2007, 104, 17204-17209.

45. Selkoe, D.J. Alzheimer's disease. In the beginning. Nature 1991, 354, 432-433.

46. Nawrot, B.; Antoszczyk, S.; Maszewska, M.; Kuwabara, T.; Warashina, M.; Taira, K.; Stec, W.J. Efficient inhibition of beta-secretase gene expression in HEK293 cells by tRNAVal-driven and CTE-helicase associated hammerhead ribozymes. Eur. J. Biochem. 2003, 270, 3962-3970. 
47. Kanamori, T.; Nishimaki, K.; Asoh, S.; Ishibashi, Y.; Takata, I.; Kuwabara, T.; Taira, K.; Yamaguchi, H.; Sugihara, S.; Yamazaki, T.; Ihara, Y.; Nakano, K.; Matuda, S.; Ohta, S. Truncated product of the bifunctional DLST gene involved in biogenesis of the respiratory chain. EMBO J. 2003, 22, 2913-2923.

48. Ohta, S.; Ohsawa, I. Dysfunction of mitochondria and oxidative stress in the pathogenesis of Alzheimer's disease: On defects in the cytochrome c oxidase complex and aldehyde detoxification. J. Alzheimers Dis. 2006, 9, 155-166.

49. Onuki, R.; Bando, Y.; Suyama, E.; Katayama, T.; Kawasaki, H.; Baba, T.; Tohyama, M.; Taira, $\mathrm{K}$. An RNA-dependent protein kinase is involved in tunicamycin-induced apoptosis and Alzheimer's disease. EMBO J. 2004, 23, 959-968.

50. Spillantini, M.G.; Schmidt, M.L.; Lee, V.M.; Trojanowski, J.Q.; Jakes, R.; Goedert, M. Alphasynuclein in Lewy bodies. Nature 1997, 388, 839-840.

51. Steece-Collier, K.; Maries, E.; Kordower, J.H. Etiology of Parkinson's disease: Genetics and environment revisited. Proc. Natl. Acad. Sci. USA 2002, 99, 13972-13974.

52. Maries, E.; Dass, B.; Collier, T.J.; Kordower, J.H.; Steece-Collier, K. The role of alpha-synuclein in Parkinson's disease: Insights from animal models. Nat. Rev. Neurosci. 2003, 4, 727-738.

53. Hayashita-Kinoh, H.; Yamada, M.; Yokota, T.; Mizuno, Y.; Mochizuki, H. Down-regulation of alpha-synuclein expression can rescue dopaminergic cells from cell death in the substantia nigra of Parkinson's disease rat model. Biochem. Biophys. Res. Commun. 2006, 341, 1088-1095.

54. Kowall, N.W.; Hantraye, P.; Brouillet, E.; Beal, M.F.; McKee, A.C.; Ferrante, R.J. MPTP induces alpha-synuclein aggregation in the substantia nigra of baboons. Neuroreport 2000, 11, 211-213.

55. Grzelinski, M.; Bader, N.; Czubayko, F.; Aigner, A. Ribozyme-targeting reveals the rate-limiting role of pleiotrophin in glioblastoma. Int. J. Cancer 2005, 117, 942-951.

56. Benson, V.L.; Khachigian, L.M.; Lowe, H.C. DNAzymes and cardiovascular disease. Br. J. Pharmacol. 2008, 154, 741-748.

57. Czubayko, F.; Riegel, A.T.; Wellstein, A. Ribozyme-targeting elucidates a direct role of pleiotrophin in tumor growth. J. Biol. Chem. 1994, 269, 21358-21363.

58. Powers, C.; Aigner, A.; Stoica, G.E.; McDonnell, K.; Wellstein, A. Pleiotrophin signaling through anaplastic lymphoma kinase is rate-limiting for glioblastoma growth. J. Biol. Chem. 2002, 277, 14153-14158.

59. Bowden, E.T.; Stoica, G.E.; Wellstein, A. Anti-apoptotic signaling of pleiotrophin through its receptor, anaplastic lymphoma kinase. J. Biol. Chem. 2002, 277, 35862-35868.

60. Grzelinski, M.; Steinberg, F.; Martens, T.; Czubayko, F.; Lamszus, K.; Aigner, A. Enhanced antitumorigenic effects in glioblastoma on double targeting of pleiotrophin and its receptor ALK. Neoplasia 2009, 11, 145-156.

61. Laaroubi, K.; Delbe, J.; Vacherot, F.; Desgranges, P.; Tardieu, M.; Jaye, M.; Barritault, D.; Courty, J. Mitogenic and in vitro angiogenic activity of human recombinant heparin affin regulatory peptide. Growth Factors 1994, 10, 89-98.

62. Czubayko, F.; Schulte, A.M.; Berchem, G.J.; Wellstein, A. Melanoma angiogenesis and metastasis modulated by ribozyme targeting of the secreted growth factor pleiotrophin. Proc. Natl. Acad. Sci. USA 1996, 93, 14753-14758. 
63. Vrati, S.; Giri, R.K.; Razdan, A.; Malik, P. Complete nucleotide sequence of an Indian strain of Japanese encephalitis virus: Sequence comparison with other strains and phylogenetic analysis. Am. J. Trop. Med. Hyg. 1999, 61, 677-680.

64. Santoro, S.W.; Joyce, G.F. A general purpose RNA-cleaving DNA enzyme. Proc. Natl. Acad. Sci. USA 1997, 94, 4262-4266.

65. Appaiahgari, M.B.; Vrati, S. DNAzyme-mediated inhibition of Japanese encephalitis virus replication in mouse brain. Mol. Ther. 2007, 15, 1593-1599.

Sample Availability: Not available

(C) 2010 by the authors; licensee MDPI, Basel, Switzerland. This article is an Open Access article distributed under the terms and conditions of the Creative Commons Attribution license (http://creativecommons.org/licenses/by/3.0/). 